\title{
Nitrogen cycling in two temperate Zostera marina beds: seasonal variation
}

\author{
Nils Risgaard-Petersen*, Lars Ditlev Mørck Ottosen \\ Institule of Biological Sciences, Department of Microbial Ecology, University of Aarhus, Ny Munkegade Bldg. 540, \\ 8000 Århus C, Denmark
}

\begin{abstract}
Exchange of dissolved inorganic N (DIN) between 2 eelgrass vegetated sediments and the water column along with denitrification, plant uptake and loss of $\mathrm{N}$ were measured monthly throughout a full year. The eelgrass beds acted as strong sinks for DIN in the spring and summer months. In autumn the beds acted as DIN sources, whereas during the winter months the beds had reestablished their sink capacity, although exchange rates were much lower than during the spring. The seasonal variation in DIN exchange between the water column and eelgrass beds was mainly controlled by the balance between benthic $\mathrm{N}$-mineralization and plant $\mathrm{N}$-uptake, while denitrification was of minor importance. Although plants and probably other associated primary producers were the dominant $\mathrm{N}$ sink, there was no accumulation of $\mathrm{N}$ in the living biomass on an annual scale. Model calculation of eelgrass decomposition furthermore suggested that most of the $\mathrm{N}$ bound to sloughed plant material was liberated to the environment within 1 yr. Only during the spring summer period was more nitrogen taken up by the beds than was released via decomposition of plant material. Therefore only in that period could the beds be considered as $\mathrm{N}$ sinks. The uptake of DIN by the eelgrass beds was significantly higher than the DIN uptake at unvegetated sites during the spring and summer period, whereas outside this period there was no significant difference between DIN fluxes measured at vegetated and unvegetated sites. Denitrification activity in the eelgrass vegetated sediments was similar to the activity in unvegetated sediments. It is suggested that the presence of eelgrass will not alter estuarine $N$-retention on an annual scale. However, during the spring and summer period when eelgrass beds are superior DIN sinks compared to unvegetated sediments, the temporal retention of $N$ in the eelgrass biomass and detritus pool may reduce nutrient availability for other phototrophic organisms. The presence of eelgrass in $\mathrm{N}$-limited areas may therefore reduce pelagic primary production.
\end{abstract}

KEY WORDS: Denitrification · Plant $\mathrm{N}$-uptake $\cdot$ Plant $\mathrm{N}$-losses $\cdot$ DIN fluxes

\section{INTRODUCTION}

Benthic microalgae and seagrasses may be significant primary producers in estuaries subjected to moderate N-load (Duarte 1995, Borum 1996, Borum \& Sand-Jensen 1996). During maximal growth in the spring and summer, assimilatory uptake of $\mathrm{N}$ by these primary producers may both reduce the diffusive loss of $\mathrm{N}$ from the sediment to the water column and enhance the flux of $\mathrm{N}$ from the water column towards the bottom (Sundbäck \& Granéli 1988, Rizzo 1990, Rysgaard et al. 1996, Risgaard-Petersen et al. 1998, Hansen et al. 1999).

•E-mail: nils.risgaard-petersen@biology.au.dk
The retention of $\mathrm{N}$ in the biomass of the benthic primary producers is most likely only temporary. It probably has little or no promoting effect at all on the annual $\mathrm{N}$-retention in estuaries, as much of the assimilated $\mathrm{N}$ may re-enter the environment via decomposition, grazing or leaching. This is in contrast to the fate of denitrified or buried $N$, but similar to the fate of plant-bound carbon (Duarte \& Cebrian 1996).

The temporal storage of nutrients in the benthic community may, however, influence phytoplankton nutrient availability, and thus ecosystem productivity. Cerco \& Seitzinger (1997) showed through model simulations that benthic microalgae communities can enhance annual primary production in the water column, because water column nutrients were transferred 
to the sediment via algae uptake during periods with high nutrient concentrations. When nutrients were scarce during summer, decomposition of the algae biomass caused the release of nutrients, which then could fuel the production of nutrient-limited pelagic primary producers. It has been proposed that rooted macrophytes can have the opposite effect on phytoplankton nutrient availability (Sand-Jensen \& Borum 1991, Risgaard-Petersen et al. 1998).

Eelgrass vegetated sediments can be more significant sinks for dissolved $\mathrm{NO}_{3}{ }^{-}$and $\mathrm{NH}_{4}{ }^{+}$than sediments with microalgae communities during the entire springsummer period (Risgaard-Petersen et al. 1998). The $N$ taken up by the eelgrass beds in that period is mainly allocated into plant tissue, whereas permanent removal via denitrification is of minor importance (Rysgaard et al. 1996, Risgaard-Petersen et al. 1998). However, the implication of plant $\mathrm{N}$-assimilation is that large quantities of $\mathrm{N}$ accumulate in the biomass during the growth season (Pedersen \& Borum 1993) and the turnover time of that $N$ is relatively long ( 27 to $60 \mathrm{~d}$, as judged from data of Pedersen \& Borum 1993 and data of Risgaard-Petersen et al. 1998). During the spring and summer $\mathrm{N}$ is liberated from the beds mainly via loss and export of leaves (Risgaard-Petersen et al. 1998), which are known to decompose relatively slowly (Harrison 1989, Buchsbaum et al. 1991, Enriquez et al. 1993). Assimilated $\mathrm{N}$ is therefore retained for long periods before it is available for new production. It is possible that this ability of the plants to sequester dissolved N may last the entire growth season, and that nutrients mainly are liberated from the beds outside this period when nutrients are likely to be flushed out of the estuary and phytoplankton growth is lightlimited.

Only a few studies, however, have addressed nutrient exchange between the water column and sediments vegetated with marine angiosperms (e.g. Rysgaard et al. 1996, Risgaard-Petersen et al. 1998, Hansen et al. 1999), and these studies do not include the temporal aspect in sufficient detail. Consequently, it is difficult to evaluate conclusively the impact of benthic macrophytes on estuarine $\mathrm{N}$-cycling from what is presently known. In order to contribute to a better understanding of the role of benthic primary producers in estuarine nutrient cycling, we focus here on the seasonal variation in nutrient exchange between the water column, and sediments vegetated with eelgrass Zostera marina. The aim of our study was to describe the annual variations in dissolved inorganic $N$ (DIN) exchange between the water column and the integrated eelgrass- sediment system, in order to identify the periods when the beds acts as sink or sources for DIN. Furthermore, we wanted to clarify the role of denitrification versus plant $\mathrm{N}$-uptake in such systems, in order to elucidate the nature of $\mathrm{N}$-retention in eelgrass beds. We therefore measured both rates of denitrification and rates of plant $\mathrm{N}$-uptake. To evaluate the time span for temporal retention of $\mathrm{N}$ in the eelgrass biomass, we measured losses and turnover of plant-bound $\mathrm{N}$ and estimated the release of $\mathrm{N}$ from the detritus pool using reported values for eelgrass decomposition. The impact of eelgrass beds on estuarine nutrient exchange was evaluated by comparing denitrification and DIN flux rates obtained in this study with rates obtained in previous studies of bare sediments.

\section{MATERIALS AND METHODS}

Study site. Nitrogen cycling was studied from March 1997 to February 1998 in both a sheltered and a windexposed Zostera marina bed. The sheltered sampling site was located in Risgårde Bredning, Limfjorden, Denmark. The area of Risgårde Bredning is $48.4 \mathrm{~km}^{2}$ and $~ 50 \%$ of the area is shallow, i.e. 0.5 to $1 \mathrm{~m}$ deep. At $\sim 450 \mathrm{~m}$ from land the depth gradually increases, reaching a maximum of $6 \mathrm{~m} \sim 800 \mathrm{~m}$ from land. The $\mathrm{N}$-load to the estuary is mainly coupled to freshwater discharge, and amounted to $149.9 \mathrm{t} \mathrm{yr}^{-1}$ in 1995 (Kaas et al. 1996). At the sampling site Junget Beach $\left(56^{\circ} 46.17^{\prime} N, 9^{\circ} 6.82^{\prime} E\right), Z$. marina covers $80 \%$ of the seafloor at 0.5 to $1 \mathrm{~m}$ depth. The coverage decreases with increasing depth, and the depth limit for the plants is approximately $2 \mathrm{~m}$ (Counties of Ringkøbing, Viborg \& Nordjylland 1997). The sampling station was located at a mean water depth of $1 \mathrm{~m}$ in a sheltered area $-50 \mathrm{~m}$ from land. The sediment was sandy silt down to approximately $10 \mathrm{~cm}$. Below this depth it consisted mostly of clay.

The wind-exposed sampling site was located in the Bight of Aarhus, Aarhus, Denmark. The area of the bight is $315 \mathrm{~km}^{2}$, and the depth increases steadily to $10 \mathrm{~m}$ at a distance 500 to $1000 \mathrm{~m}$ from the coastline. The N-load to the bight is mainly coupled to freshwater discharge, and amounted to $1715 \mathrm{t} \mathrm{yr}^{-1}$ in 1995 (Kaas et al. 1996). At the sampling site Vejlby Fed ( $56^{\circ} 12.14^{\prime} \mathrm{N}, 10^{\circ} 17.13^{\prime}$ E) Zostera marina covers $60 \%$ of the seafloor from 0.4 to $5.2 \mathrm{~m}$, and the depth limit for the plants is $\sim 5.2 \mathrm{~m}$ (County of Aarhus 1995). The sampling station was located at a mean water depth of $1 \mathrm{~m}$ in a wind-exposed area $~ 30 \mathrm{~m}$ from land. The sediment at the sampling site was sandy.

Sampling. Sampling was performed monthly at both sites. Sediment cores $(\mathrm{n}=6)$ with intact plants were sampled with a stainless steel core sampler (Fig. 1A) in transparent Plexiglas tubes (i.d. $20 \mathrm{~cm}$, height $50 \mathrm{~cm}$ ). These cores were used for laboratory measurements of denitrification and exchange of $\mathrm{O}_{2}, \mathrm{NH}_{4}{ }^{+}, \mathrm{NO}_{2}{ }^{-}$and $\mathrm{NO}_{3}{ }^{-}$between the sediment-eelgrass community and 

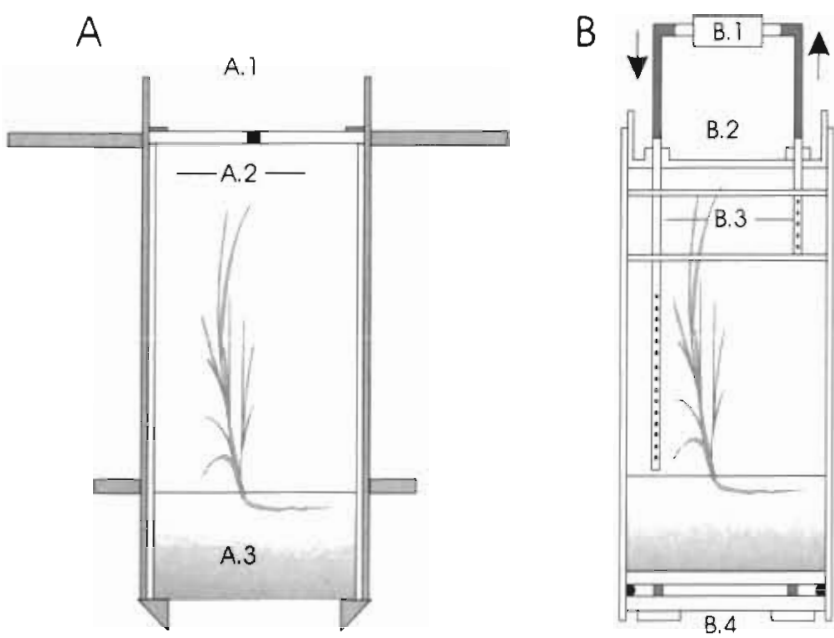

Fig. 1. (A) Core sampler, with Plexiglas tube (A.2) equipped with a lid (A.1). A.3 is the sediment core. (B) Incubation system, with water pump (B.1), connected to perforated acrylic tubes (B.3), maintaining a continuous re-circulation of the water in the incubation tube. The tube is sealed at the top with a transparent floating Plexiglas lid (B.2) and at the bottom sealed with a cover that consists of an elastic rubber ring squeezed between 2 PVC discs with bolts (B.4)

the water column. Filtered (GF/C filters) water samples for nutrient analysis were collected at the field site in $20 \mathrm{ml}$ polyethylene vials and frozen $\left(-20^{\circ} \mathrm{C}\right)$ on return to the laboratory. Water samples for $\mathrm{O}_{2}$ determinations were collected with glass syringes, transferred to glass vials (Exetainer, Labco, High Wycombe, UK) and Winkler reagents were added immediately. In situ water for the incubations was collected in 301 polyethylene jars.

In order to measure in situ growth rate of eelgrass, sods of plants $(n=2)$ were collected in plastic boxes $(30 \times 40 \mathrm{~cm})$. All the leaves of 30 to 40 shoots in these boxes were pierced with a hypodermic needle, which made it possible to estimate growth of the leaves within a defined period (Sand-Jensen 1975). The boxes with the pierced plants were hereafter placed at $1 \mathrm{~m}$ water depth at the field site. After 1 to $3 \mathrm{wk}$ of incubation in the field, depending on the season, growth was measured from the displacement of the needle marks on the young growing leaves relative to the mark on the nongrowing leaves of the pierced shoots. To obtain information about the seasonal variation in the $\mathrm{N}$-state of eelgrass, additional plants $(n=6)$ were collected on each sampling occasion and separated into leaves and groups of roots-rhizomes of different ages for later analysis of the tissue-specific N-content (Borum et al. 1989). On return to the laboratory the lengths of the different plant parts were measured, and then plants were dried to constant weight at $90^{\circ} \mathrm{C}$. The dried material was stored in polyethylene vials for later $\mathrm{N}$ determinations.
Flux and denitrification measurements. The cores with intact plants were allowed to equilibrate in the laboratory for $12 \mathrm{~h}$ in 2 open $120 \mathrm{l}$ tanks with aerated water from the field site, held at in situ temperature. Mixing of the water column above the sediment cores was provided by a water circulation system, constructed from a pump and perforated Plexiglas tubes (Fig. 1B). The setup prevented damage of leaves, while adequate mixing of the water column was assured. A flushing rate of $1.5 \mathrm{l} \mathrm{min}-1$ was set as standard for all incubations. With this flushing rate the water was completely mixed within less than $30 \mathrm{~s}$, as judged from dye dispersion experiments in similar Plexiglas tubes with artificial plants.

Fluxes and denitrification rates were measured both in the light and the dark. Light was provided by three $500 \mathrm{~W}$ halogen lamps, positioned 10 to $50 \mathrm{~cm}$ above the surface of the water in the tubes. Actual irradiance was adjusted to fit the monthly mean PAR for the given incubation month (Fig. 2). Light data were obtained from the Danish Institute of Agricultural Sciences Research Center at Foulum.

Incubations were performed in 2 sessions. First, the cores selected for flux measurements ( $n=3$ ) were incubated in the light, while cores selected for denitrification measurements $(n=3)$ were incubated in the dark. When this session was completed the water in the tubes was renewed and light exposure reversed. After completing both incubation sessions, the cores were sacrificed and the eelgrass plants were sorted, counted and separated into leaves and root/rhizomes, and subsequently dried to constant weight at $90^{\circ} \mathrm{C}$. Subsamples of dried plant material were stored in plastic vials for later $\mathrm{N}$ determination.

Flux measurements were initiated after closing the core tubes with transparent floating lids made of Plexiglas. During the 4 to $12 \mathrm{~h}$ incubation time, depending on the season, 5 water samples for determination of $\mathrm{O}_{2}$ and $\mathrm{N}$-species were collected periodically ( $\mathrm{n}=5$ ) from the water column of each core tube using a glass syringe. Samples for $\mathrm{O}_{2}$ were transferred to $12 \mathrm{ml}$ glass vials (Exetainer) and Winkler reagents were added immediately. Samples for $\mathrm{NO}_{3}{ }^{-} / \mathrm{NO}_{2}{ }^{-}$and $\mathrm{NH}_{4}{ }^{+}$determinations were frozen in polyethylene vials $\left(-20^{\circ} \mathrm{C}\right)$.

Denitrification was measured by ${ }^{15} \mathrm{~N}$ methodology. For each of the cores selected for denitrification measurements, ${ }^{15} \mathrm{NO}_{3}{ }^{-}$was added to the water column to a final concentration of about $50 \mu \mathrm{M}{ }^{15} \mathrm{~N}$. The added ${ }^{15} \mathrm{NO}_{3}{ }^{-}$was then allowed to equilibrate with the sediment pore water for approximately $30 \mathrm{~min}$. Then the cores were closed with the transparent floating lids and incubated for 4 to $12 \mathrm{~h}$, depending on the season. Water samples for ${ }^{15} \mathrm{NO}_{3}{ }^{-}$determinations were collected regularly 5 times during the incubations. In order to determine the amount of ${ }^{15} \mathrm{~N}$-labeled $\mathrm{N}_{2}\left({ }^{29} \mathrm{~N}_{2},{ }^{30} \mathrm{~N}_{2}\right)$ 

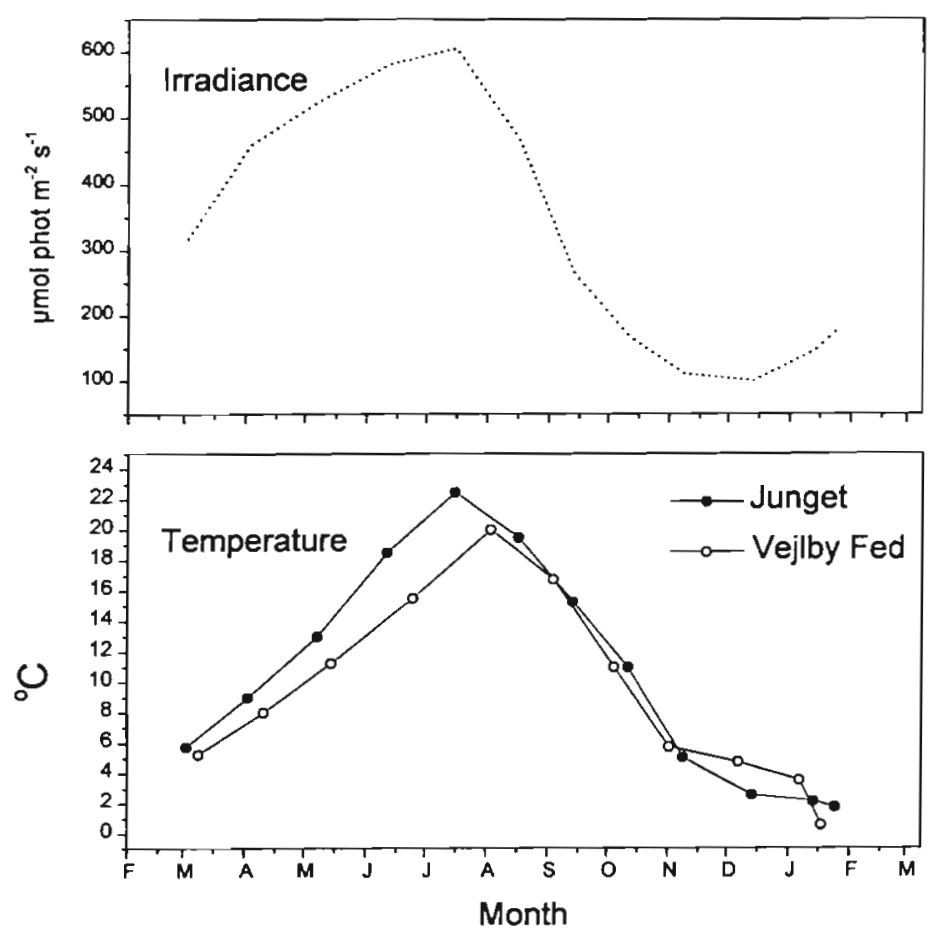

Fig. 2. Incubation irradiance and temperature during the flux and denitrification measurements

that accumulated in the sediment and the water column, subsamples of sediment and water were collected periodically $(\mathrm{n}=5$ ) with an acrylic tube (i.d. $1 \mathrm{~cm}$, height $30 \mathrm{~cm}$ ), to which $0.5 \mathrm{ml} 7 \mathrm{M} \mathrm{ZnCl}_{2}$ was added to inhibit microbial activity. Hereafter water and sediment in the acrylic tube were mixed to a homogeneous slurry, and a sample of the slurry was transferred to $6 \mathrm{ml}$ glass vials (Exetainer), preserved with an additional 250 pl $7 \mathrm{M} \mathrm{ZnCl}_{2}$ and stored at $4{ }^{\circ} \mathrm{C}$ for later ${ }^{29} \mathrm{~N}_{2}$ and ${ }^{30} \mathrm{~N}_{2}$ concentration determinations.

Analysis. Concentrations of $\mathrm{NO}_{3}{ }^{-}$and $\mathrm{NO}_{2}{ }^{-}$were determined on a HPLC system (Sycam, Gliching, Germany) equipped with a UV detector $(220 \mathrm{~nm}$, model Spectro monitor 3200, Thermoseparation Products, Riviera Beach, Florida) and an anion column (4 by $250 \mathrm{~mm}$ Aniontrenn LCA A14, Sycam) held at $60^{\circ} \mathrm{C}$. The eluent was $\mathrm{NaCl}(40 \mathrm{mM})$, with a flow rate of $1.5 \mathrm{ml} \mathrm{s}^{-1}$. Ammonium was analyzed colorimetrically as described by Bower \& Holm-Hansen (1980). Oxygen was determined by the Winkler titration method (Grasshoff et al. 1983) within a few hours of sampling. Concentrations of ${ }^{29} \mathrm{~N}_{2}$ and ${ }^{30} \mathrm{~N}_{2}$ in sediment-water suspensions were determined on a gas chromatograph in line with a triple collector isotope ratio mass spectrometer (Sira Series II, VG Isotech, Middlewich, UK) as described by Risgaard-Petersen \& Rysgaard (1995). The ${ }^{15} \mathrm{~N}$-at. $\%$ of $\mathrm{NO}_{3}{ }^{-}$in the ${ }^{15} \mathrm{NO}_{3}{ }^{-}$amended flux chambers was measured by mass spectrometry after biological reduction to $\mathrm{N}_{2}$ (Risgaard-Petersen et al. 1993). Nitrogen content of the dried plant material was measured on a Carlo Erba $\mathrm{C} / \mathrm{N}$ elemental analyzer.

Calculations. Fluxes of $\mathrm{NO}_{3}{ }^{-}+\mathrm{NO}_{2}{ }^{-}, \mathrm{NH}_{4}{ }^{+}$and $\mathrm{O}_{2}$ were calculated from the slope of the regression line obtained from plots of solute or gas concentration against time (see Fig. 3 for examples). For every measured compound, the regression model was evaluated using $F$-statistics. Non-significant $(p>0.05)$ correlation between concentration and time was interpreted as zero flux.

The concentrations of ${ }^{29} \mathrm{~N}_{2}$ and ${ }^{30} \mathrm{~N}_{2}$ in the ${ }^{15} \mathrm{NO}_{3}{ }^{-}$amended cores increased linearly with time for all incubations (see Fig. 3 for examples) and the ratio between ${ }^{29} \mathrm{~N}_{2}$ and ${ }^{30} \mathrm{~N}_{2}$ was therefore constant during each of the performed incubations. In situ denitrification activity (i.e. denitrification of ${ }^{14} \mathrm{NO}_{3}{ }^{-}$) could thus be estimated with the isotope-pairing technique from the production rates of ${ }^{29} \mathrm{~N}_{2}$ and ${ }^{30} \mathrm{~N}_{2}$ (Nielsen 1992). Production rates of these isotopic species were calculated in the same way as fluxes of inorganic $\mathrm{N}$-species and $\mathrm{O}_{2}$ were calculated.

In situ denitrification activity was calculated as follows:

In situ denitrification $=\frac{F^{29}}{2 F^{30}}\left(F^{29}+2 F^{30}\right)$

where $F^{29}$ and $F^{30}$ are the production rates of ${ }^{29} \mathrm{~N}_{2}$ and ${ }^{30} \mathrm{~N}_{2}$ respectively (units: $\mu \mathrm{mol} \mathrm{N}_{2} \mathrm{~m}^{-2} \mathrm{~h}^{-1}$ ).

The in situ denitrification activity was divided into coupled nitrification-denitrification $\left(D_{\mathrm{n}}\right)$ and denitrification of $\mathrm{NO}_{3}{ }^{-}$supplied from the water column $\left(D_{\mathrm{w}}\right)$ as described by Nielsen (1992):

$$
\begin{gathered}
D_{\mathrm{w}}=\left(F^{29}+2 F^{30}\right)\left(\frac{100}{{ }^{15} \mathrm{~N} \text {-at. } \%}-1\right) \\
D_{\mathrm{n}}=\text { In situ denitrification }-D_{\mathrm{w}}
\end{gathered}
$$

where ${ }^{15} \mathrm{~N}$-at. \% is the ${ }^{15} \mathrm{~N}$-at. \% of $\mathrm{NO}_{3}{ }^{-}$in the water column.

The diurnal flux and denitrification rates were calculated from rates obtained in the light multiplied by the daylength plus the rates obtained in darkness multiplied by the length of the dark period (i.e. $24 \mathrm{~h}$ - daylength\}. Daylength was defined as the average time from sunrise to sunset for the specific month.

Eelgrass growth, $\mathrm{N}$-incorporation, $\mathrm{N}$-translocation from old to young plant parts, $\mathrm{N}$-uptake from the environment and losses of tissue-bound $\mathrm{N}$ were calculated from data obtained during the in situ growth measurements, from the $\mathrm{N}$-content of the plants and from the shoot density (Pedersen \& Borum 1993). 

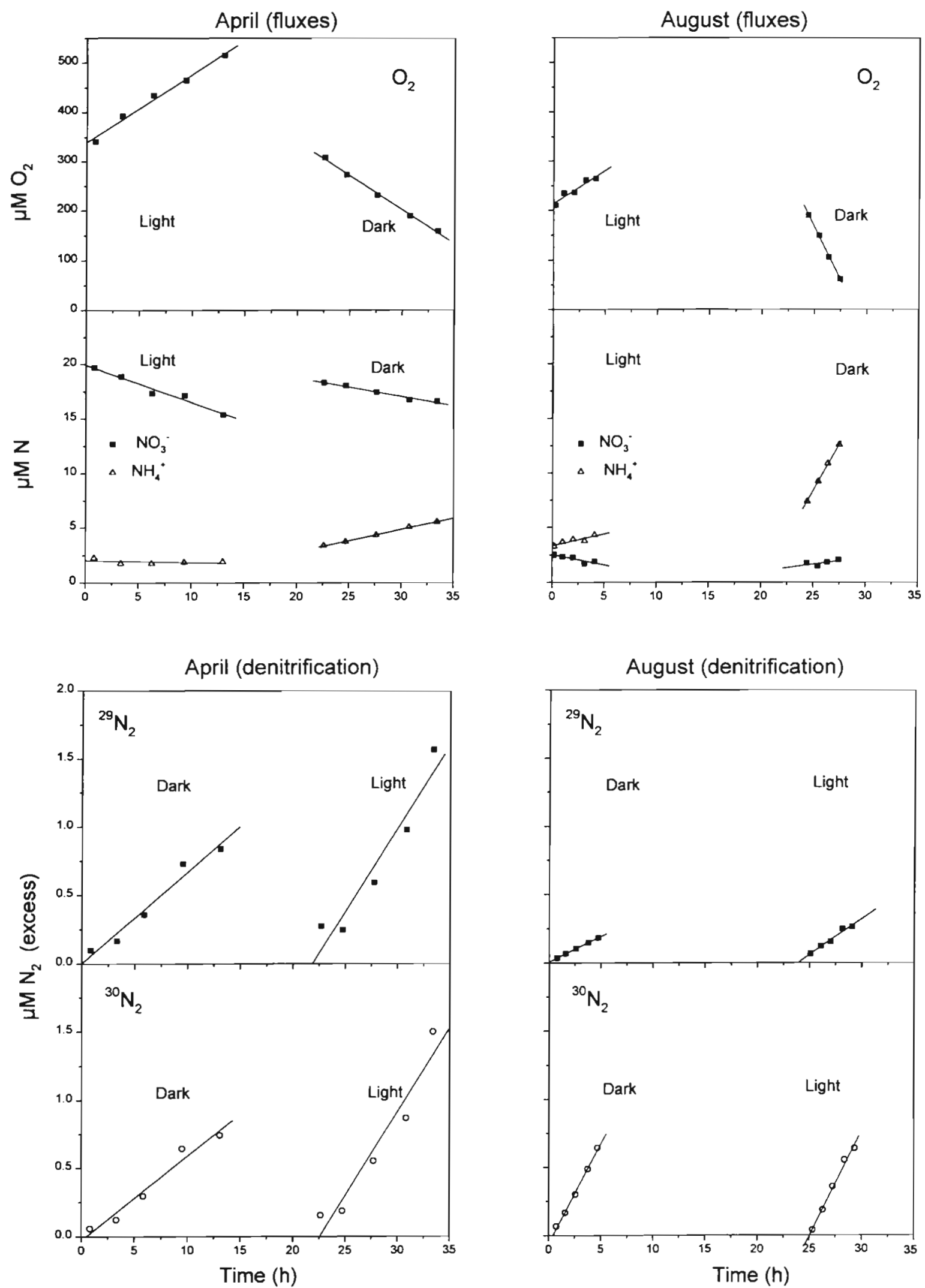

Fig. 3. Concentration changes of solutes and gases during incubations in April and August of vegetated sediments from the Junget field site 
The procedure for estimating $\mathrm{N}$-dynamics of the plants was as follows (leaf no. 1 represents the inner and youngest leaf, and leaf no. 5 or 6 the outermost and oldest leaf of the individual plants). Leaf production was calculated as the product of average leaf growth rate, the specific dry weight of leaf no. 4, and the density of shoots in the sampled sediment cores used for flux and denitrification measurements. Root-rhizome internode production was estimated from the production of new leaves, since 1 new root-rhizome internode is produced for each new leaf (Pedersen \& Borum 1993). Growth was calculated as the average internode production multiplied by the average dry weight of the fully-grown internodes and associated side roots. Loss of above-ground biomass was calculated from leaf growth rates and changes in the leaf biomass between the sampling periods. We were not able to obtain good estimates of the below-ground biomass due to high variability, so loss of tissue from the root system was not estimated. $\mathrm{N}$-incorporation into leaves or root was calculated as leaf or root production multiplied by the average $\mathrm{N}$-content of leaf no. 3 , or the $\mathrm{N}$-content of the fully grown root-rhizome group. Uptake of $\mathrm{N}$ in the above-ground biomass was calculated as the increase in leaf-bound $\mathrm{N}$ from month $n$ to month $n+1$ plus $\mathrm{N}$ losses. Loss of leaf-bound $\mathrm{N}$ from the eelgrass biomass was calculated as the product of the loss rate and the $\mathrm{N}$-content of the oldest leaf (leaf no. 5 or 6). Translocation of $\mathrm{N}$ from old to new leaves was calculated as the difference between incorporation and uptake of $\mathrm{N}$. In order to estimate the uptake of $\mathrm{N}$ by roots and rhizomes, and hence the total N-uptake of the plants, we assumed that the ratio between uptake and incorporation for root-rhizomes was similar to that for the leaves. Root-rhizome $\mathrm{N}$-uptake was thus calculated as the product between this ratio and root-rhizome $\mathrm{N}$-incorporation.

SPSS for windows, release 8.0.0 (SPSS Inc.), was used for statistical treatment of the data. One-way ANOVA tests were used to analyze for seasonal variations in flux and denitrification rates on the different sites, since 2-way ANOVA indicated significant interactions between site and date variables.

\section{RESULTS}

\section{Seasonal variations in $\mathrm{O}_{2}$ fluxes}

Throughout the year $\mathrm{O}_{2}$ flux rates were highest in the light, suggesting significant primary production at any season. Gross primary pro- duction (GPP, calculated as the sum of $\mathrm{O}_{2}$ flux in the light and the respiration, measured as dark $\mathrm{O}_{2}$ uptake) was highest at Junget on an annual scale (Fig. 4). At both stations GPP showed significant seasonal variations (ANOVA, $\mathrm{p} \ll 0.001$ ). At Junget GPP increased rapidly during the spring when both light and biomass were augmented (see Figs. $2 \& 7 \mathrm{~A}$ ). Maximum activity was reached in June. Following a decline in aboveground biomass and light, GPP declined to constant low values from November to February. At Vejlby Fed, GPP reached a maximum in August and declined hereafter to constant low values from December to February.

Community oxygen consumption, calculated as dark $\mathrm{O}_{2}$ uptake $\times 24 \mathrm{~h}$, was similar at the 2 stations on an annual scale (Fig. 4). At both sites significant seasonal variations were observed (ANOVA, $\mathrm{p} \ll 0.001$ ). At Junget oxygen consumption increased during the spring and reached a maximum in July, when the temperature of the water column peaked (Fig. 2). Hereafter the activity declined to constant low values from December to February, in accordance with the decline in temperature and above-ground biomass (see Figs. 2 \& 7A). At Vejlby Fed maximum activity was reached in August, and hereafter community respiration declined to constant low activity from December to February

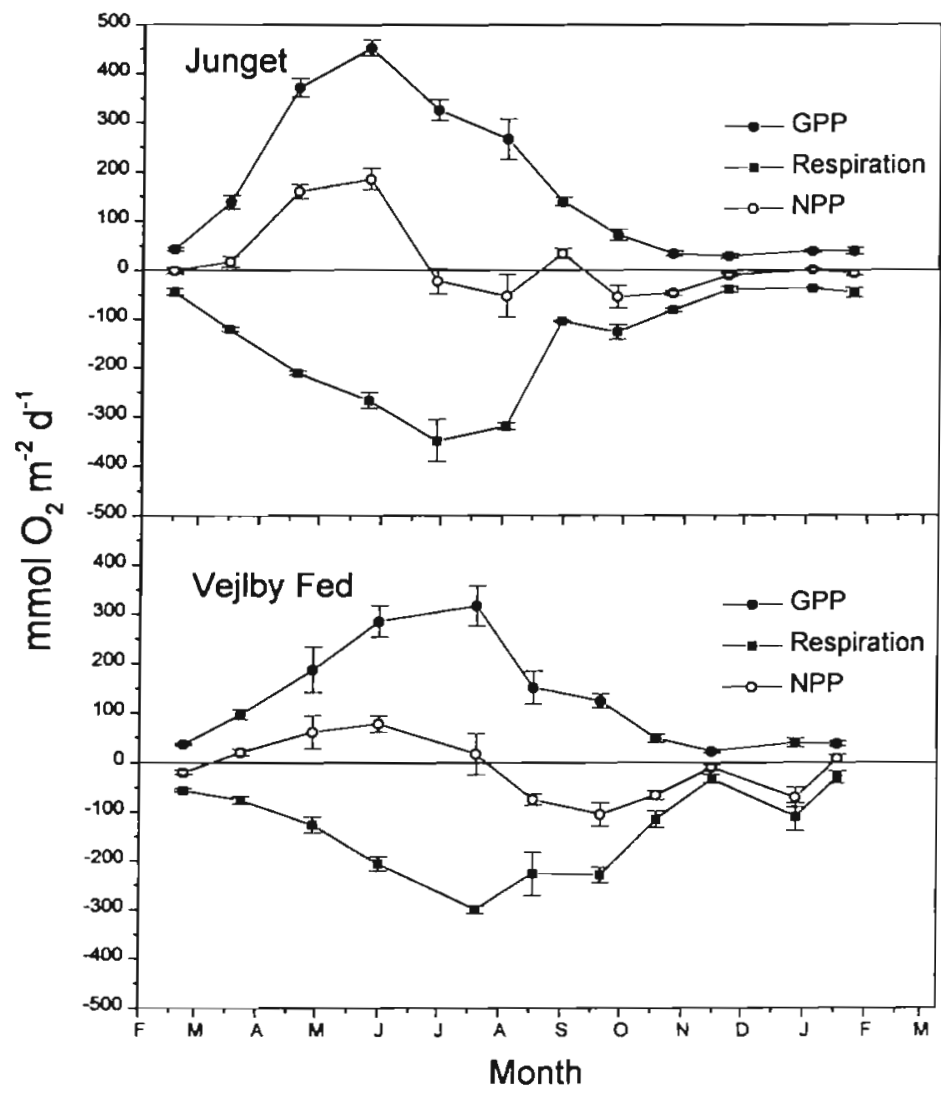

Fig. 4. Annual variation in gross primary production in terms of $\mathrm{O}_{2}(\mathrm{GPP})$, community respiration, and net primary production (NPP) at the 2 field sites 
The eelgrass vegetated sediment at Junget was net $\mathrm{O}_{2}$ producing on a yearly scale, while the eelgrass bed at Vejlby Fed was net $\mathrm{O}_{2}$ consuming. This difference was mainly caused by differences in GPP rates, since community respiration was similar at the 2 sites. At both sites we observed significant seasonal variation in the $\mathrm{O}_{2}$ balance (ANOVA, $\mathrm{p} \ll 0.001$ ). The eelgrass bed at Junget was net $\mathrm{O}_{2}$ producing from March to June (Fig. 4), and highest net production rates were observed in June when GPP peaked, while community respiration was still increasing. Hereafter the bed was net $\mathrm{O}_{2}$ consuming. Maximum net consumption rates were observed in August and September, when GPP was declining; afterwards net consumption rates declined due to decreasing community respiration. The eelgrass bed at Vejlby Fed was net $\mathrm{O}_{2}$ producing from March to August with maximum rates in June. In the following months the bed was net $\mathrm{O}_{2}$ consuming. Maximum net consumption rates were reached in August to October, after which net $\mathrm{O}_{2}$ consumption slightly decreased due to decreasing respiration.

\section{Seasonal variation in DIN fluxes}

On an annual scale $\mathrm{NO}_{3}{ }^{-}$was taken up from the water column by both of the beds studied (Fig. 5). The $\mathrm{NO}_{3}{ }^{-}$uptake was $10 \times$ higher at Junget than at Vejlby Fed, probably due to better $\mathrm{NO}_{3}{ }^{-}$availability at Junget during periods of high plant $\mathrm{N}$ uptake rates. The significant seasonal variations in $\mathrm{NO}_{3}^{-}$flux at both sites (ANOVA, $\mathrm{p}<0.005$ ) were not correlated with the $\mathrm{NO}_{3}{ }^{-}$ concentration in the water column $\left(\mathrm{R}^{2}<0.1\right)$. At Junget $\mathrm{NO}_{3}{ }^{-}$uptake increased during the spring and early summer (March to July) parallel to a decrease in water column $\mathrm{NO}_{3}{ }^{-}$. From August to February 1998, the $\mathrm{NO}_{3}^{-}$ influx declined to constant low value, despite increasing $\mathrm{NO}_{3}{ }^{-}$concentrations in the autumn. At Vejlby Fed the $\mathrm{NO}_{3}{ }^{-}$uptake decreased from March to May, coinciding with decreasing $\mathrm{NO}_{3}{ }^{-}$concentrations in the water column. During the rest of the season the uptake stayed low $\left(\ll 2 \mu \mathrm{mol} \mathrm{m} \mathrm{m}^{-2} \mathrm{~d}^{-1}\right)$, including autumn and winter when $\mathrm{NO}_{3}{ }^{-}$increased slightly in the water column.

On an annual scale both of the beds released $\mathrm{NH}_{4}{ }^{+}$to the water column. Annual $\mathrm{NH}_{4}{ }^{+}$release was $2 \times$ higher at Junget than at Vejlby Fed. Both stations were characterized by significant seasonal variations in flux rates (ANOVA, $\mathrm{p}<0.005$ ) (Fig. 5). At Junget $\mathrm{NH}_{4}{ }^{+}$was released from the bed throughout the year, except during the winter months, when the $\mathrm{NH}_{4}{ }^{+}$flux was directed from the water column towards the beds. Lowest release rates were observed during the spring and summer months, when the eelgrass bed was net $\mathrm{O}_{2}$ producing. Ammonia release peaked in August, after the bed had switched from being net $\mathrm{O}_{2}$ producing to net $\mathrm{O}_{2}$ consuming. The $\mathrm{NH}_{4}{ }^{+}$efflux remained relatively high until October. Hereafter $\mathrm{NH}_{4}^{+}$efflux declined parallel to a decline in community respiration. In the winter months $\mathrm{NH}_{4}{ }^{+}$was taken up from the water column,

At Vejlby Fed $\mathrm{NH}_{4}{ }^{+}$was taken up from the water column from March to May and from December to February. From June to November $\mathrm{NH}_{4}{ }^{+}$was released from the bed to the water column.

On a yearly scale the eelgrass bed at Junget was a sink for DIN, while the bed at Vejlby Fed was a moderate source. These differences in the DIN source-sink state coincided with the observation that the bed at Junget was net $\mathrm{O}_{2}$ producing, while the bed at Vejlby Fed was net $\mathrm{O}_{2}$ consuming on an annual scale. Significant seasonal variations in DIN source-sink status were observed at both sites (ANOVA, Junget $p \ll$ 0.001, Vejlby Fed: $p=0.003$ ) (Fig. 5). At Junget, periods with high DIN uptake from the water column coincided with the periods when the bed was net $\mathrm{O}_{2}$ producing, i.e. March to June. Highest uptake rates were observed in May. From July to November, when the beds were net $\mathrm{O}_{2}$ consuming, DIN was released to the water column. The highest release rates of DIN were observed in August. At Vejlby Fed there was a net uptake of DIN from the water column from March to May. Hereafter DIN was released from the bed until October. At this station highest DIN release rates were also observed in August.

\section{Seasonal variation in denitrification}

Denitrification rates were approximately $5 \times$ higher at Junget than at Vejlby Fed on an annual scale (Fig. 6). We attribute this difference to differences in $\mathrm{NO}_{3}{ }^{-}$accessibility due to difference in $\mathrm{NO}_{3}{ }^{-}$concentrations in the water column (Fig. 6). The $\mathrm{NO}_{3}^{-}$concentration may have influenced denitrification directly, and probably also indirectly by affecting the root uptake of the plants and thus the competition between roots and nitrifying/denitrifying bacteria. Only at Junget did our data indicate seasonal variations in denitrification activity (ANOVA, $p=0.001$ for the Junget bed, $\mathrm{p} \gg 0.05$ for the Vejlby Fed bed, Fig. 6). Maximum activity at this site was observed in April when the $\mathrm{NO}_{3}{ }^{-}$concentration in the water column peaked. Lowest activities were observed in January and February, when $\mathrm{NO}_{3}{ }^{-}$was relatively high but $\mathrm{O}_{2}$ data suggested overall low heterotrophic activity. From March to June approximately $60 \%$ of the activity was based on $\mathrm{NO}_{3}{ }^{-}$supplied from the water column. From July to September, when $\mathrm{NO}_{3}{ }^{-}$was scarce in the water column, approximately $80 \%$ of the de- 

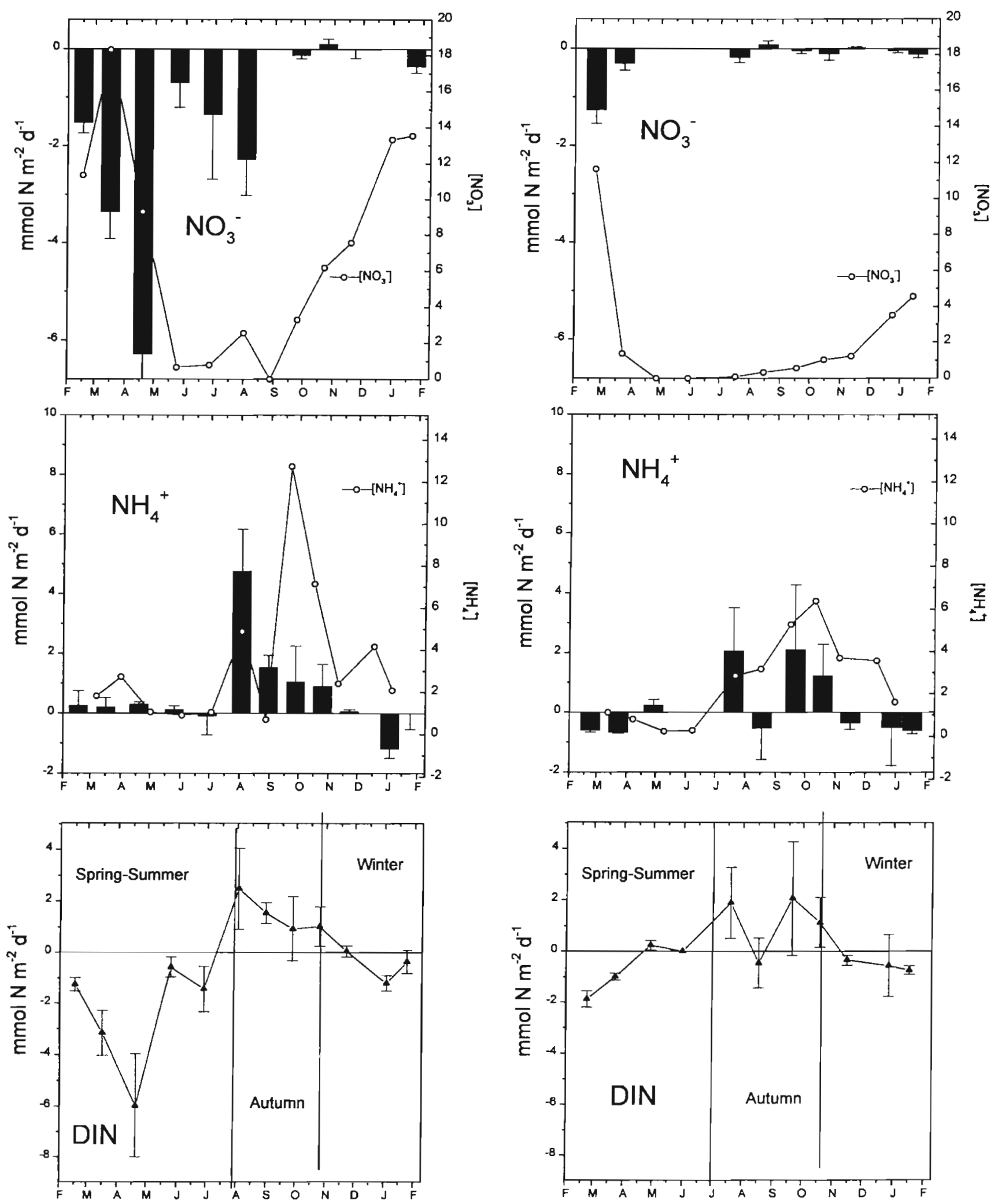

Junget

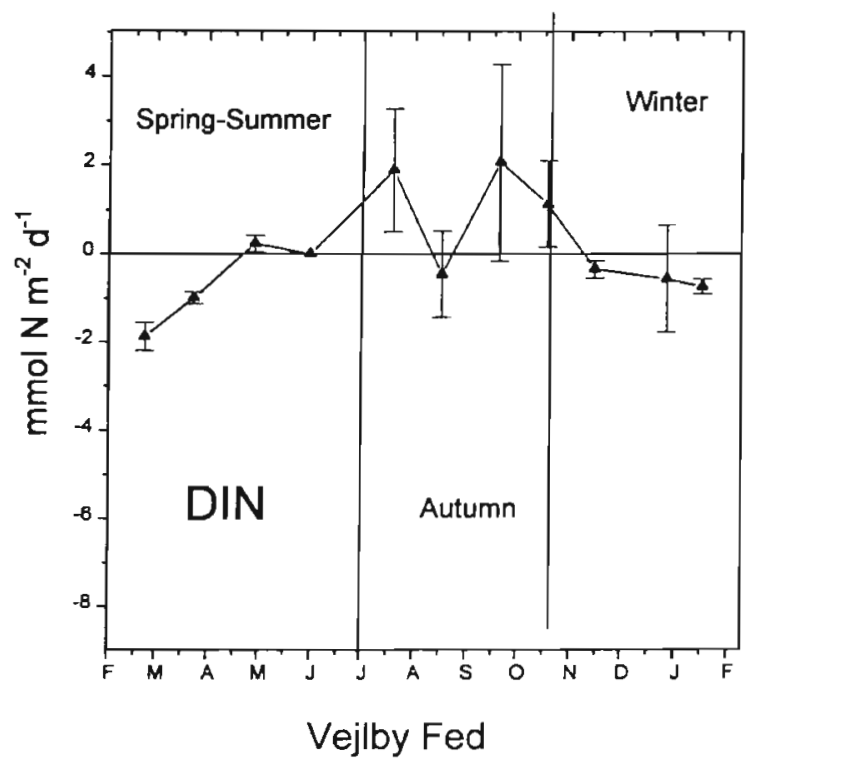

Fig. 5. Seasonal variation in $\mathrm{NO}_{3}{ }^{-}, \mathrm{NH}_{4}{ }^{+}$and dissolved inorganic nitrogen (DIN) fluxes at the 2 field sites. Concentrations of $\mathrm{NO}_{3}{ }^{-}$ and $\mathrm{NH}_{4}{ }^{*}$ are given in $\mu \mathrm{m}$ 

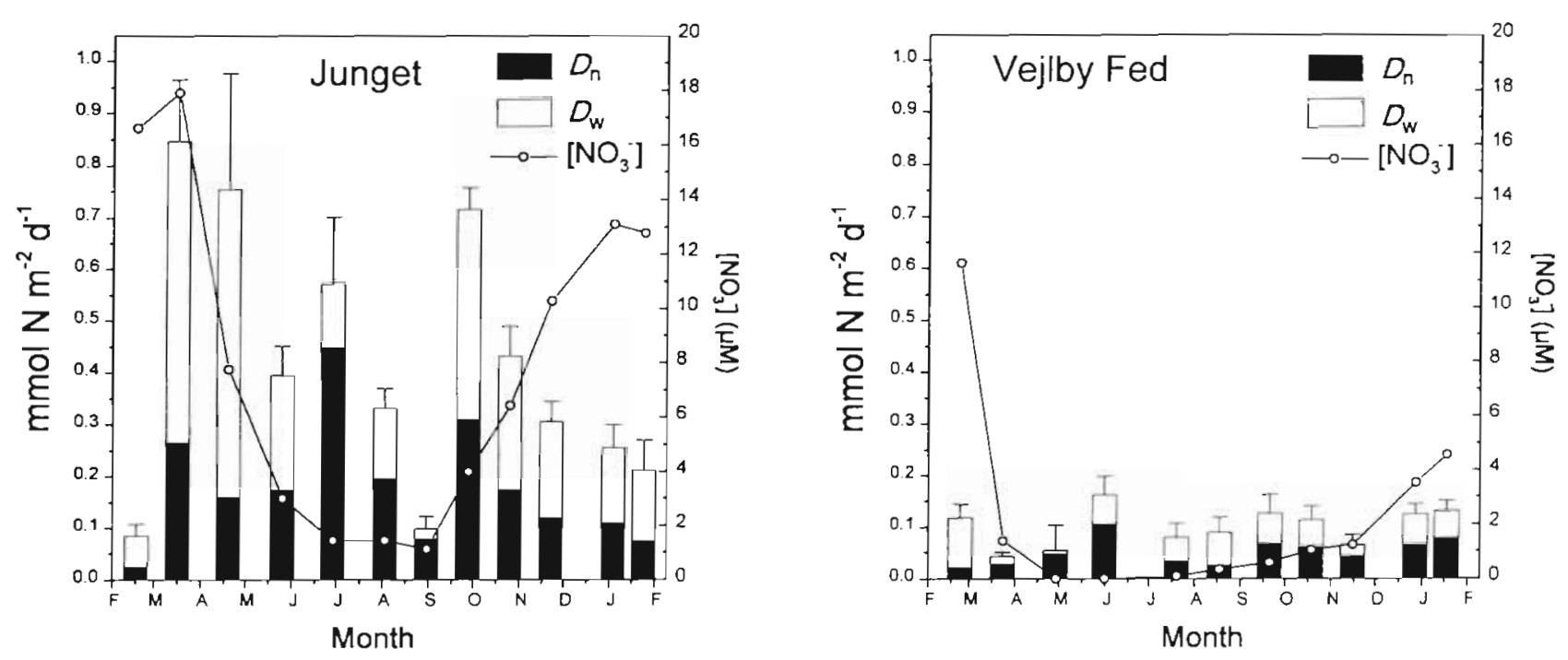

Fig. 6. Annual variation in denitrification at Junget and at Vejlby Fed. $D_{n}=$ coupled nitrification-denitrification $D_{\mathrm{w}}=$ bottom water supported denitrification

nitrification activity was based on $\mathrm{NO}_{3}{ }^{-}$produced by sedimentary nitrification. Hereafter the water column was the dominant source.

\section{Seasonal variations in eelgrass growth, $\mathrm{N}$-uptake and $\mathrm{N}$-losses}

Plant growth rates measured in the field were slightly lower at Junget than at Vejlby Fed on an annual scale (Fig. 7), which apparently conflicts with our $\mathrm{O}_{2}$ data. This discrepancy between growth and $\mathrm{O}_{2}$ data could be due to the differences in methodology used for primary production measurements. Alternatively, it might reflect that $\mathrm{O}_{2}$ producing communities of epiphytes and microphytobenthos were more important at Junget Beach bed than at the Vejlby Fed site. This was clear from visual observations in the field, but we did not make any attempt to quantify the role of these organisms.

At Junget growth increased rapidly from April to June and then a rapid attenuation was observed. From September until February the activity was constant at $<10 \%$ of the activity at the start of the most active growth season. At Vejlby Fed growth peaked in July (Fig. 7B), and from September rates declined fast and reached constant low values $<20 \%$ of the spring and summer values. At Junget most of the energy was allocated to leaf growth (leaf growth/root growth: 2.6), whereas similar leaf and root growth rates were observed at Vejlby Fed (leaf growth/root growth: 1.4). This different growth pattern was probably caused by a difference in wave exposure. The sediment at Vejlby Fed is coarser and more wave-exposed than the Junget sediments, thus demanding relatively better anchoring of the plants.

Rates of $\mathrm{N}$-incorporation were similar at the 2 stations on an annual scale (Fig. 7). The temporal pattern in $\mathrm{N}$-incorporation was similar to the trend for plant growth at both stations with maximum activity from April to August. N-incorporation in that period constituted between 75 and $88 \%$ of the total annual activity. During most of the investigation period, the plants extracted their $\mathrm{N}$ mainly from external sources, as indicated by the similarity between $\mathrm{N}$-incorporation and $\mathrm{N}$-uptake rates (Fig. 7). Translocation of $\mathrm{N}$ from old to new growing tissue satisfied only about 10 to $20 \%$ of the annual N-demand. During the winter months (November to February), however, between 60 and $90 \%$ of the $\mathrm{N}$-demand of the plants was satisfied via this process. For both stations $\mathrm{N}$-uptake from the environment followed the same trends as $\mathrm{N}$-incorporation, with maximum rates in June and July and minimum rates in the winter.

Both of the beds were subjected to a considerable loss of tissue-bound $\mathrm{N}$ via detachment of leaves during most of the period investigated (Fig. 7). Loss of leafbound $\mathrm{N}$ increased during the spring and reached $\mathrm{a}$ maximum in July and August. Only in the spring and early summer period did this loss fall behind the rate of leaf $\mathrm{N}$-uptake. Consequently, only in this period did we observe an increase in the pool of $\mathrm{N}$ bound to the above-ground biomass, while outside the spring and summer period the pool was stripped of $\mathrm{N}$. On an annual scale a steady state between loss and gain was achieved, as indicated by the almost identical biomass values at the beginning and at the end of the investigation period. 

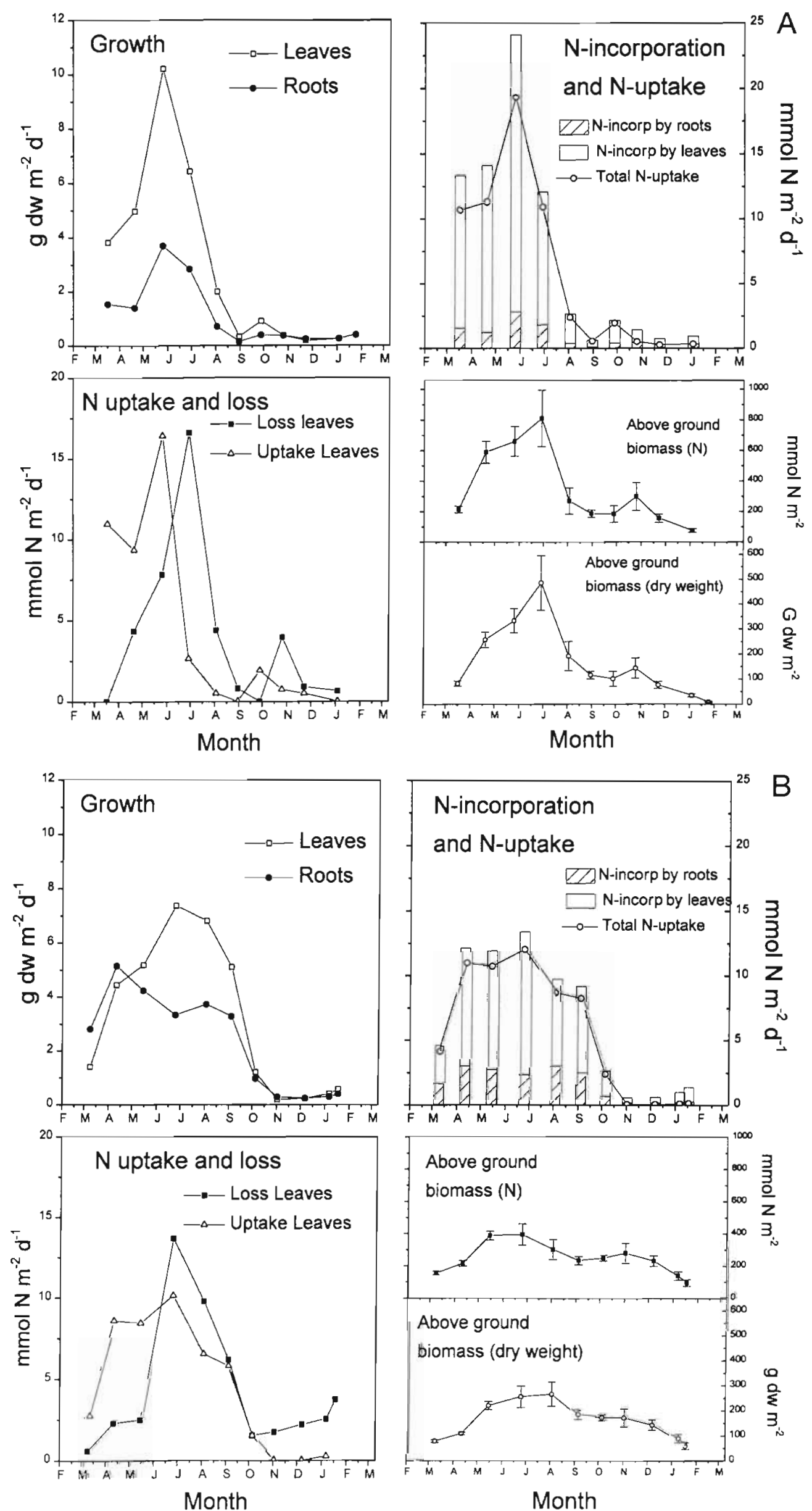

Fig. 7. Annual variation in growth rates, plant $\mathrm{N}$-incorporation, plant N-uptake, loss of leaf-bound $N$ from the eelgrass biomass, and seasonal variation in above ground biomass for the Zostera marina bed at (A) Junget and (B) Veijlby Fed. Note that the estimate of total plant $\mathrm{N}$-uptake is based on the assumption that the ratio between uptake and incorporation is similar for roots and leaves (see 'Materials and methods') 
Shoot density was constant at 700 to 1000 ind. $\mathrm{m}^{-2}$ from March to July at Junget. In August and September the density of shoots declined to values below 400 . Hereafter a slight increase to $\sim 600$ shoots $\mathrm{m}^{-2}$ was observed from October to February. At Vejlby Fed the shoot density declined steadily from $\sim 1500$ to $\sim 800$ shoots $\mathrm{m}^{-2}$ during the period of investigation (data not shown).

\section{DISCUSSION}

\section{Seasonal variations in DIN: the role of assimilation and denitrification}

In this study, we observed a seasonal pattern of DIN exchange between the eelgrass beds and the water column (Fig. 5) similar to that reported for marine systems with microphytic benthic primary production (e.g. Rizzo et al. 1992, Rysgaard et al. 1995, Cerco \& Seitzinger 1997). In such systems photoautotrophic assimilation plays an important role as a DIN sink and consequently as a regulator of the $\mathrm{N}$ fluxes across the sediment-water interface (e.g. Sundbäck et al. 1991, Rizzo et al. 1992, Rysgaard et al. 1993). For the eelgrass beds investigated in the present study, we identify photoautotrophic assimilation as the major sink, while the role of denitrification was comparatively modest. This is indicated from the following observations.

First, denitrification was insignificant compared to the rates of plant $\mathrm{N}$-uptake during most of the investigation period (Figs. $6 \& 7$ ); as yearly average denitrification was less than $4 \%$ of plant $\mathrm{N}$-uptake rates, and only during the winter months did the process approach or exceed the activity of the plants. The systems might well have been even more controlled by assimilatory processes than indicated by our results, since our plant $N$-uptake rates does not necessarily fully represent all assimilatory processes acting in the system. Benthic microalgae and epiphytes, for instance, might have played a major role in nutrient exchange between the eelgrass beds and the environment. Those organisms can contribute significantly to the productivity of seagrass beds (e.g. Borum \& Wium-Andersen 1980 , Brouns \& Heijs 1986, Murray \& Wetzel 1987, Moncrieff et al. 1992), and they often have more efficient $N$ uptake kinetics than eelgrass plants and a higher $\mathrm{N}$-demand (Sand-Jensen \& Borum 1991). Hence, their $\mathrm{N}$-uptake rates might exceed those of the plants. Hansen et al. (1999) thus found that benthic microalgae inhabiting the sediment surface between eelgrass plants were the major sinks for DIN in the spring. The aim of this study was, however, not to evaluate the importance of the different primary producers in the eelgrass beds, but to investigate the eelgrass bed as a single system, though it is a community of various organisms.
A second indication of the low impact of denitrification on the system comes from the observation that denitrification based on bottom water $\mathrm{NO}_{3}{ }^{-}$was only between 18 (Junget) and 26\% (Vejlby Fed) of the net $\mathrm{NO}_{3}{ }^{-}$flux into the sediment (average for the entire study period). Only in the winter period did denitrification approach or exceed the measured net $\mathrm{NO}_{3}{ }^{-}$fluxes into the sediment, suggesting significant alternative $\mathrm{NO}_{3}{ }^{-}$sinks during most of the investigation period. We cannot exclude nitrate-ammonification activity in this context, since this process has been reported to constitute a major reduction pathway for $\mathrm{NO}_{3}{ }^{-}$in seagrass vegetated sediments (Boon et al. 1986, Rysgaard et al. 1996). However, for both of the beds studied here the $\mathrm{NO}_{3}{ }^{-}$influx exceeded the $\mathrm{NH}_{4}{ }^{+}$efflux by a factor of 5 to 20 during the spring and summer (April to August), where the flux of $\mathrm{NO}_{3}{ }^{-}$represented more than $75 \%$ of the annual net input of $\mathrm{NO}_{3}{ }^{-}$. Therefore, even if nitrate-ammonification was a significant sink for bottom water $\mathrm{NO}_{3}{ }^{-}$, most of the $\mathrm{N}$ that entered this pathway would necessarily have been assimilated within the eelgrass beds.

A third indication of the dominance of assimilatory processes over denitrification comes from the fact that denitrification was of little importance as a sink for $\mathrm{N}$ regenerated in the sediment. Sedimentary $N$-regeneration activity was $5.1 \mathrm{mmol} \mathrm{N} \mathrm{m}^{-2} \mathrm{~d}^{-1}$ for Junget and $5.6 \mathrm{mmol} \mathrm{N} \mathrm{m}^{-2} \mathrm{~d}^{-1}$ for Vejlby fed (yearly averages) when estimated from the difference between the input of DIN from the water column (Fig. 5) and the sum of $\mathrm{N}$ needed to support denitrification (Fig. 6), plant $\mathrm{N}$-uptake (Fig. 7) and diffusional loss of $\mathrm{NH}_{4}{ }^{+}$to the water column (Fig. 5). Coupled nitrification-denitrification removed less than $4 \%$ of that (yearly average). Only during the winter (November to February), when the estimated $N$-regeneration activity in the eelgrass vegetated sediments was low (average values: $0.3 \mathrm{mmol}$ $\mathrm{m}^{-2} \mathrm{~d}^{-1}$ at Junget and $0.2 \mathrm{mmol} \mathrm{m} \mathrm{m}^{-2} \mathrm{~d}^{-1}$ at Vejlby Fed) did denitrification remove approximately $12 \%$ of the liberated N. Since less than $13 \%$ of the $N$ liberated via mineralization escaped the sediment as DIN as an annual mean, the major part (>75\%) must have been assimilated by plants. We emphasize that the calculated $\mathrm{N}$-regeneration activity is only a minimum estimate, since the additional $N$ needed to support the $\mathrm{N}$-demand of benthic microalgae and epiphytes is not included. The partition between denitrification and assimilation as $\mathrm{N}$ sinks was therefore probably much more displaced toward assimilation than indicated above.

The superior role of photothropic organisms, compared to denitrifying bacteria, as sink for DIN indicated from our results is equivalent to what has been reported from Zostera noltii (Rysgaard et al. 1996) and Zostera marina vegetated sediments (Risgaard-Petersen 
et al. 1998) and may result from the following conditions. First, diffusional resistance against $\mathrm{N}$-uptake from the water column is likely to be less severe for eelgrass leaves, epiphytes and microphytobenthos surrounded by a thin boundary layer than for denitrifying bacteria situated millimeters below the sediment surface. Second, plants and microalgae have much better access to the pool of reduced $\mathrm{N}$ (such as $\mathrm{NH}_{4}{ }^{+}$in the water column and the sediment) than denitrifying bacteria, because $\mathrm{N}$ in this form is directly used as a $\mathrm{N}$-source by marine phototrophs. Denitrification of $\mathrm{N}$ bound in $\mathrm{NH}_{4}{ }^{+}$, on the other hand, is only possible when the process is coupled to nitrification. Recent data suggest that nitrification activity is insignificant in temperate eelgrass vegetated sediments (Ottosen et al. 1999). Finally, plants may crowd out bacteria in a sediment environment that is occupied by the root/rhizome system.

The overall insignificant role of denitrification as $\mathrm{N}$ sink in the eelgrass beds leads us to suggest that the balance between the $\mathrm{N}$-demand of the phototrophic organisms and the intensity of sedimentary $\mathrm{N}$-regeneration was the major factor controlling the status of the eelgrass beds as sources or sinks for DIN. Thus DIN was extracted from the water column in the spring and summer months (April to July/August), when the beds showed highest photosynthetic activity and the $\mathrm{N}$ uptake by the eelgrass plants was maximal (Fig. 7). This was most likely because the overall phototrophic $\mathrm{N}$-demand was too high to be satisfied alone by endogenous $\mathrm{N}$-regeneration. When a decline in light availability (Fig. 2) reduced photosynthesis in late summer and autumn (August/September to November, Fig. 4), the $\mathrm{N}$-uptake of the eelgrass plants also declined (Fig. 7). The beds became net $\mathrm{O}_{2}$ consuming indicating that photothropic-related activity (in terms of assimilation of $\mathrm{C}$ and $\mathrm{N}$ ) was lower than the production of $\mathrm{C}$ and DIN via heterothropic mineralization activity. As the reduced ability of the photosynthetic community to retain regenerated $\mathrm{N}$ was not compensated by an equivalent increase in denitrification activity, the eelgrass beds turned into DIN sources. However, even though plant $\mathrm{N}$-uptake was reduced, the mass balance suggests that more than $60 \%$ of the $\mathrm{N}$ regenerated in the sediments was taken up by the plants. Only during the winter months (December to February), when photosynthesis and plant $\mathrm{N}$-uptake rates were at their minimum levels due to low light and temperature (Fig. 2), did denitrification seem to play a role as a DIN sink equivalent to unvegetated sediments. During this period low temperatures, and probably also the scarcity of accessible organic matter, were likely the factors responsible for the reduced heterotrophic activity, which is reflected in both our denitrification and $\mathrm{O}_{2}$ data.

\section{Eelgrass beds as $\mathrm{N}$ sinks}

Findings from the present study showed a dominance of assimilatory processes over denitrification, which lead us to focus on the fate of the tissue-bound $\mathrm{N}$ in the eelgrass plants. The pool of $\mathrm{N}$ bound in the tissue of the living above-ground biomass in the investigated eelgrass beds did not accumulate on an annual scale (Fig. 7). This is consistent with the data of Pedersen \& Borum (1993), who also found a similar lack of N-accumulation in the root biomass, and we assume that this may also hold true for the beds investigated in the present study. With this assumption it is clear that most of the DIN taken up by the beds was only temporarily retained in the plants. The loss of nitrogen from the living biomass was most likely the consequence of shedding old leaves and roots (Pedersen \& Borum 1993), as this material will undergo decomposition either inside or outside the eelgrass beds. During the decomposition process, eelgrass detritus is a net source of $N$ (Harrison 1989, Buchsbaum et al. 1991). We estimated this release of $\mathrm{N}$ from the decomposing biomass in order to evaluate the efficiency of the temporal retention, and to evaluate the changing capacity of the eelgrass beds as sinks for N. We assumed 1st order decay of the eelgrass detritus pool (Enríquez et al. 1993), and a continuous supply of material to the detritus pool corresponding to the measured loss rates of plant-bound N (Fig. 7). We used a Nbased rate constant for leaf decomposition $\left(0.0438 \mathrm{~d}^{-1}\right)$. This rate constant was found in a recent Danish litterbag study conducted over a $250 \mathrm{~d}$ period from May to January in Roskilde Fjord, Denmark (M. F. Pedersen, Roskilde University, pers. comm.). Given these assumptions, it was calculated that between 95 and $98 \%$ of the detritus pool produced from March 97 to February 98 was decomposed during the period of investigation, and therefore most of the immobilized nutrients were liberated and available for transport or new production within 1 yr. The estimated N-release from decomposition peaked in June and July for both beds (Fig. 8). The average monthly release was highest in the spring and summer. Only in the early spring (March and April) did the DIN influx to the beds exceed the rate of $\mathrm{N}$-release from the detritus pool. However, during the entire spring and summer, the release of $\mathrm{N}$ from the detritus pool was between 40 and $50 \%$ of the plant $\mathrm{N}$-uptake rates; while outside this period the estimated $\mathrm{N}$-release rate was on average $2 \times$ higher than the uptake rates (Figs. $7 \& 8$ ). Our calculations thus indicate that only during the spring and summer was more $\mathrm{N}$ transferred to the system than released to the environment via export and decomposition of leaves. Since bacterial $\mathrm{N}_{2}$ fixation may only account for a few percent of this $\mathrm{N}$ transfer (McGlathery et al. 1998), the beds could be considered as true sinks for easy accessible $\mathrm{N}$ in that period. 


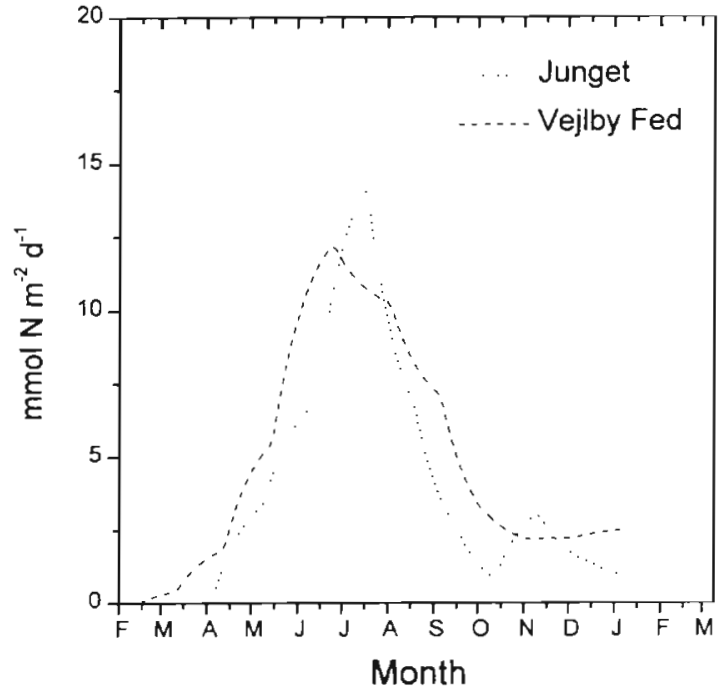

Fig. 8. Estimated release of nitrogen from the sloughed leaf material

\section{Eelgrass beds versus unvegetated sediments}

In benthic systems without seagrass, denitrification generally plays a much more dominant role as sink both for bottom water $\mathrm{NO}_{3}{ }^{-}$and for DIN regenerated in the sediment. Data from these types of estuarine sediments thus show denitrification of bottom water $\mathrm{NO}_{3}{ }^{-}$ to be $>50 \%$ of the annual $\mathrm{NO}_{3}{ }^{-}$flux into the sediments (e.g. Rysgaard et al. 1995, Oglivie et al. 1997, Trimmer et al. 1998), while coupled nitrification-denitrification has been shown to remove 15 to $60 \%$ of the regenerated inorganic $N$ (Seitzinger 1988). As indicated above, these conditions are only met in the eelgrass beds during the winter period when the activity of the plants is at minimum, and evidently the introduction of an additional component in the benthic system (i.e. the eelgrass), induces major changes in the structure of the $\mathrm{N}$-cycle. Moreover, previous studies show that rates of $\mathrm{N}$-mineralization and rates of coupled nitrificationdenitrification are altered in the presence of seagrass (Boon et al. 1986, Cafferey \& Kemp 1990, Ottosen 1999). An analysis of the extent to which those differences cause differences in denitrification activity and DIN exchange for vegetated and unvegetated sites was done by comparing the flux and denitrification rates in the eelgrass beds studied here, with data from similar unvegetated sediments. Those data were supplied by the National Environmental Research Institute, Silkeborg, Denmark. The data set (unpublished, but annual mean rates from the field sites are given by Dalsgaard et al. 1999) originate from studies of the $\mathrm{N}$-cycle in 8 Danish shallow estuaries, conducted between 1992 and 1995. Each of the estuaries was represented by 4 to 7 stations and studied at monthly inter- vals. Flux and denitrification data in these studies were generated using the methodology described by Rysgaard et al. (1995), which is similar to the methodology used in the present study, except that sediment samples were incubated in $5.2 \mathrm{~cm}$ i.d. cores with magnetic stir bars. To facilitate a comparison between vegetated and unvegetated sites, we only used data from unvegetated sediments exposed to concentrations of $\mathrm{NO}_{3}{ }^{-}$ similar to the concentration in the water column above the seagrass beds studied here i.e. $<12 \mu \mathrm{M} \mathrm{NO}_{3}$ -

There was no significant difference between rates of denitrification of bottom water $\mathrm{NO}_{3}{ }^{-}\left(D_{\mathrm{W}}\right)$ measured at vegetated and unvegetated sites (Table 1, ANOVA, $p>0.005)$. The rate of coupled nitrification-denitrification, however, was lowest in the eelgrass vegetated sediments (Table 1, ANOVA, $\mathrm{p}=0.003$ ). This indicates that the presence of seagrass will not increase total estuarine $\mathrm{N}$-retention, except via a possible burial of refractory plant compounds. To our knowledge, the fraction of the production of plant-bound $\mathrm{N}$ that is permanently buried in the sediment is not quantified in seagrass studies reported in the literature. Therefore, the relative importance of this possible pathway cannot be evaluated conclusively by discussing results obtained in this study. However, our model calculation of $\mathrm{N}$-release from the decomposing eelgrass detritus suggests that burial is an insignificant sink for plantbound $\mathrm{N}$.

During the spring and summer period when eelgrass plants (Fig. 7), and probably other photosynthetic compounds as well, had maximal impact on the $\mathrm{N}$-cycle via their assimilation, net uptake rates of DIN were highest at the 2 eelgrass vegetated sediments (Table 2 , ANOVA, $\mathrm{p}=0.01$ ). Both in the late autumn and the winter period, however, flux rates measured in the present study were not significantly different from the activity at the unvegetated sediments (Table 2, ANOVA, $p>$ 0.05). The apparent statistical similarity between flux rates at vegetated and unvegetated sites during the late summer and autumn period might be the result of

Table 1. Denitrification (mmol $\mathrm{m}^{-2} \mathrm{~d}^{-1}$ ) in Zostera marina vegetated and bare sediments. $D_{n}$ represents coupled nitrification-denitrification, and $D_{w}$ is the bottom water supported denitrification. Standard error of the mean is given in parenthesis, and $\mathrm{n}$ is the number of observations in each cluster. Data from the $Z$. marina beds represent the mean activity of the 2 beds investigated in this study. Bare sediment data are supplied by the National Environmental Research Institute, Silkeborg, Denmark

\begin{tabular}{|lcccc|}
\hline Sediment & \multicolumn{2}{c}{$D_{\mathrm{n}}$} & \multicolumn{2}{c|}{$D_{\mathrm{w}}$} \\
& Rate & $\mathrm{n}$ & Rate $^{\mathrm{n}}$ & $\mathrm{n}$ \\
\hline Z. marina & $0.1(0.02)$ & 23 & $0.14(0.03)$ & 23 \\
Bare sediments & $0.4(0.05)$ & 71 & $0.15(0.03)$ & 71 \\
\hline
\end{tabular}


Table 2. Seasonal variation in DIN exchange $\left(\mathrm{mmol} \mathrm{m} \mathrm{m}^{-2} \mathrm{~d}^{-1}\right)$ between the water column and Zostera marina vegetated or bare sediments. Standard error of the mean is given in parenthesis, and $\mathbf{n}$ is the number of observations in each cluster. Data from the $Z$. marina beds represent the mean activity for the 2 beds investigated in this study. Bare sediment data are supplied by the National Environmental Research Institute, Silkeborg, Denmark

\begin{tabular}{|lrlll|}
\hline \multirow{2}{*}{ Season } & \multicolumn{3}{c|}{ DIN flux } \\
& \multicolumn{2}{c}{ Z. marina } & \multicolumn{3}{c|}{ Bare sediment } \\
& Rate & $\mathrm{n}$ & & $\mathrm{n}$ \\
\hline Apr-Jul & $-1.7(0.7)$ & 8 & $0.7(0.4)$ & 29 \\
Aug-Oct & $1.0(0.5)$ & 7 & $1.0(0.5)$ & 21 \\
Nov-Feb & $-0.1(0.3)$ & 8 & $0.2(0.3)$ & 19 \\
\hline
\end{tabular}

antagonistic interactions between reduced coupled nitrification-denitrification (Table 1), of elevated mineralization (e.g. Boon et al. 1986), and the presence of assimilating plants and algae in the seagrass beds investigated. In that period such organisms probably captured most of the regenerated $N$ (see above) that otherwise would have been lost by diffusion.

\section{CONCLUSIONS}

The results of the present study show that eelgrass beds are only efficient sinks for easily accessible $\mathrm{N}$ in the spring and early summer period. In that period, the potential release of $N$ to the environment from the decomposing biomass was much lower than the overall $\mathrm{N}$-demand of the beds, and the eelgrass vegetated sediments consumed more DIN from the water column than unvegetated sediments. We were not able to demonstrate significant differences between flux rates measured at vegetated and unvegetated sites outside the season of maximal growth, and our model calculations indicate that the release of $\mathrm{N}$ from the decomposing biomass was much higher than the $\mathrm{N}$-demand of the beds. It is not clear how much of this detritusderived $\mathrm{N}$ escaped the beds via diffusion, and thus was included in the measured flux rates, and how much was released outside the beds due to export and subsequent decomposition of sloughed leaves at adjacent areas. If a major fraction of the detritus was decomposed outside the beds, then the seagrass beds can indirectly be regarded as superior sources of $\mathrm{N}$, when compared to unvegetated sediments.

The eelgrass beds mainly act as temporary sinks for $\mathrm{N}$, since assimilation of $\mathrm{N}$ was a quantitatively much more important process than denitrification, and since a large fraction of the $\mathrm{N}$ bound to plant parts will be liberated during decomposition of the detritus. The presence of eelgrass in the estuarine environment will probably not alter estuarine $\mathrm{N}$-retention on an annual scale. Our data and model calculations indicate no significant difference between total denitrification rates measured $\left(D_{\mathrm{n}}+D_{\mathrm{w}}\right)$ at vegetated and at unvegetated sites (Table 1), and no accumulation of nitrogen in either the eelgrass biomass or the detritus pool. To fully consolidate this hypothesis, however, more denitrification data from vegetated sites are needed. Likewise it is necessary to quantify the amount of tissue-bound $\mathrm{N}$ that is permanently buried in the sediment.

An important effect of eelgrass beds on estuarine $\mathrm{N}$-cycling might, however, be associated with their ability to sequester and immobilize large quantities of $\mathrm{N}$ during the growth season. Eelgrasses are, in contrast to phytoplankton, characterized by an over-wintering biomass and may start their growth and $\mathrm{N}$-uptake in early spring (Sand-Jensen 1975, Pedersen \& Borum 1993, this study: Fig. 7). It is therefore possible that the presence of eelgrass may reduce the accessibility of $\mathrm{N}$ to phytoplankton via early root and leaf uptake, thereby diminishing the likelihood of algal blooms in spring and summer. In the autumn and winter, when growth and plant $\mathrm{N}$-uptake rates are low, the vegetated sediments turn into sources for $\mathrm{N}$. However, pelagic primary production is usually light-limited in this period, and therefore cannot benefit from the input of additional $\mathrm{N}$ from the eelgrass beds. We therefore propose that the presence of eelgrass in $\mathrm{N}$-limited estuaries may reduce pelagic primary production.

Acknowledgements. Sten P. Andersen is greatly acknowledged for valuable technical assistance with this project, during both field and laboratory work. We also thank M. F. Pedersen and the National Environmental Research Institute, Silkeborg, for supplying us with additional data. L. Lohse and 2 anonymous reviewers are acknowledged for critical comments to this manuscript. This work is a contribution to the European Union ELOISE Programme in the framework of the NICE project carried out under contract MAS3-CT960048 .

\section{LITERATURE CITED}

Boon PI, Moriaty DJW, Saffigna PG (1986) Nitrate metabolism in sediments from seagrass (Zostera capricorni) beds of Moreton Bay, Australia. Mar Biol 91:269-275

Borum J (1996) Shallow water and land/sea boundaries. In: Jørgensen BB, Richardson K (eds) Eutrophication in coastal marine ecosystems. Coastal and Estuarine Studies, American Geophysical Union, Washington, DC, p 179-203

Borum J, Sand-Jensen K (1996) Is total primary production in shallow coastal marine waters stimulated by nitrogen loading? Oikos 76:406-410

Borum J, Wium-Andersen S (1980) Biomass and production of epiphytes on eelgrass (Zostera marina L.) in the Øresund, Denmark. Ophelia (Suppl) 1:57-64

Borum J, Murray L, Kemp WM (1989). Aspects of nitrogen acquisition and conservation in eelgrass plants. Aquat Bot $35: 289-300$ 
Bower CE, Holm-Hansen T (1980) A salicylate-hypoclorite method for determining ammonia in seawater. Can J Fish Aquat Sci 37:794-798

Brouns JJWM, Heijs F ML (1986) Production and biomass of the seagrass Enhalus acroides (L.f.) Royle and its epiphytes. Aquat Bot 25:21-45

Buchsbaum R, Valiela I, Swain T, Dzierzeski M, Allen S (1991) Available and refractory nitrogen in detritus of coastal vascular plants and macroalgae. Mar Ecol Prog Ser 72: 131-14

Caffrey JM, Kemp WM (1990) Nitrogen cycling in sediments with estuarine populations of Portomogeton perfoliatus and Zostera marina. Mar Ecol Prog Ser 66:147-160

Cerco CF, Seitzinger SP (1997) Measured and modeled effects of benthic algae on eutrophication in Indian RiverPhoboth Bay, Delaware. Estuaries 20:231-248

County of Aarhus (1995) Århus bugt og Kalo Vig. Technical report, County of Aarhus Press

Counties of Ringkøbing, Viborg and Nordjylland (1997) Vandmiljø overvågning: Bundvegetation 1996. Technical report, County of Viborg Press

Dalsgaard T, Rysgaard S, Chrstensen PB, Risgaard-Petersen $N$ (1999) Denitrification in Danish estuaries. In: Lomstein B (ed) Havmiljøet mod år 2000. Olesen og Olesen, Fredensborg

Duarte CM (1995) Submerged aquatic vegetation in relation to different nutrient regimes. Ophelia 41:87-112

Duarte CM, Cebrian J (1996) The fate of marine autotropic production. Limnol Oceanogr 41:1758-1766

Enríquez S, Duarte CM, Sand-Jensen K (1993) Patterns in decomposition rates among photosynthetic organisms: the importance of detritus C:N:P content. Oecologia 94: $457-471$

Grasshoff K, Erhardt M, Kremling K (1983) Methods of seawater analysis. Verlag Chemie, Weinheim

Hansen JW, Pedersen AU, Berntsen J, Rønbøg IS, Hansen LS, Lomstein BA (1999) Photosynthesis, respiration, and nitrogen uptake by different compartments of a Zostera marina community. Aquat Bot 66:281-295

Harrison PG (1989) Detrital processing in seagrass systems: a review of factors affecting decay rates, remineralization and detritivory. Aquat Bot 23:263-288

Kaas $H$, Møhlenberg F, Josefson A, Rasmussen B, KrauseJensen D, Jensen $H$, Svendsen L, Windolf J, Middelboe AL, Sand-Jensen K, Pedersen MF (1996) Marine Områder. Danske fjorde-status over miljøtilstand, årsagssammenhæenge og udvikling. Report no. 179, National Environmental Research Institution, Roskilde

McGlathery KJ, Risgaard-Petersen N, Christensen PB (1998) Temporal and spatial variation in nitrogen fixation activity in eelgrass Zostera marina rhizosphere. Mar Ecol Prog Ser 168:245-258

Moncreiff CA, Sullivan MJ, Deahnick AE (1992) Primary production dynamics in seagrass beds of Mississippi Sound: the contribution of seagrass, epiphytes, sand microflora and phytoplankton. Mar Ecol Prog Ser 87:161-171

Murray L, Wetzel RG (1987) Oxygen production and consumption associated with the major autotrophic components in two temperate seagrass communities. Mar Ecol Prog Ser 38:231-239

Nielsen LP (1992) Denitrification in sediments determined from nitrogen isotope pairing. FEMS Microbiol Ecol 86: $357-362$

Oglivie B, Nedwell DB, Harrison RM, Robinson A, Sage A
(1997) High nitrate, muddy estuaries as nitrogen sinks: the nitrogen budget of the River Clone estuary (United Kingdom). Mar Ecol Prog Ser 150:217-228

Ottosen LDM, Risgaard-Petersen N, Nielsen LP (1999) Direct and indirect measurements of nitrification and denitrification in the rhizosphere of aquatic macrophytes. Aquat Microbiol Ecol 19:81-91

Pedersen MF, Borum J (1993) An annual nitrogen budget for a seagrass Zostera marina population. Mar Ecol Prog Ser 101:169-177

Risgaard-Petersen N, Rysgaard S (1995) Nitrate reduction in sediments and waterlogged soils measured by ${ }^{15} \mathrm{~N}$ techniques. In: Alef K, Nannipieri P (eds) Methods in applied soil microbiology. Academic Press Inc, London, p 287-296

Risgaard-Petersen N, Rysgaard S, Revsbech NP (1993) A sensitive assay for determination of ${ }^{14} \mathrm{~N} /{ }^{15} \mathrm{~N}$ isotope distribution in $\mathrm{NO}_{3}{ }^{-}$. J Microbial Methods 17:155-164

Risgaard-Petersen N, Dalsgaard T, Rysgaard $S$, Kristensen PBC, Borum J, McGlathery K, Nielsen LP (1998) Nitrogen balance of a temperate eelgrass Zostera marina bed. Mar Ecol Prog Ser 174:281-291

Rizzo WM (1990) Nutrient exchanges between the water column and a subtidal benthic microalgal community. Estuaries 13:219-226

Rizzo WM, Lackey GL, Christian RR (1992) Significance of euphotic, subtidal sediments to oxygen and nutrient cycling in a temperate estuary. Mar Ecol Prog Ser 86: $51-61$

Rizzo WM, Dailey SK, Lackey GJ, Christian RR, Berry BE, Wetzel RL (1996) A metabolism-based trophic index for comparing the ecological values of shallow-water sediment habitats. Estuaries 19:247-256

Rysgaard S, Risgaard-Petersen N, Nielsen LP, Revsbech NP (1993) Nitrification and denitrification in lake and estuarine sediments measured by the ${ }^{15} \mathrm{~N}$ dilution technique and isotope pairing. Appl Environ Microbiol 59:2093-2098

Rysgaard S, Christensen PB, Nielsen LP (1995) Seasonal variation in nitrification and denitrification in estaurine sediment colonized by benthic microalgae and bioturbating infauna. Mar Ecol Prog Ser 126:111-121

Rysgaard S, Risgaard-Petersen N, Sloth NP (1996) Nitrification, denitrification and nitrate ammonification in sediments of two coastal lagoons in Southern France. Hydrobiologia 329:133-141

Sand-Jensen K (1975) Biomass, net production and growth of eelgrass (Zostera marina L.) population in Vellerup Vig, Denmark. Ophelia 14:185-201

Sand-Jensen K, Borum J (1991) Interactions among phytoplankton, periphyton, and macrophytes in temperate freshwaters and estuaries. Aquat Bot 41:137-175

Seitzinger S (1988) Denitrification in freshwater and coastal marine ecosystems: ecological and geochemical significance. Limnol Oceanogr 33:702-724

Sundbäck K, Granéli W (1988) Influence of microphytobenthos on the nutrient flux between sediment and water: $a$ laboratory study. Mar Ecol Prog Ser 43:63-69

Sundbäck K, Enoksson V, Granéli W, Petterson K (1991) Influence of sublittoral microphytobenthos on the oxygen and nutrient flux between sediment and water: a laboratory continuous-flow study. Mar Ecol Prog Ser 74: 263-279

Trimmer M, Nedwell DB, Sivyer DB, Malcolm SJ (1998) Nitrogen fluxes through the lower estuary of the river Great Ouse, England: the role of the bottom sediments. Mar Ecol Prog Ser 163:109-124 